\title{
Morphological Changes in Leech Retzius Neurons After Target Contact During Embryogenesis
}

\author{
John Jellies, Curtis M. Loer, and William B. Kristan, Jr. \\ Department of Biology, University of California, San Diego, La Jolla, California 92093
}

\begin{abstract}
Segmental variation in identified neurons may provide an opportunity to examine extrinsic influences on neuronal phenotype, since segmentally homologous neurons must contain much the same intrinsic information, having arisen from very similar or identical precursors. Two large serotonergic Retzius (Rz) cells are found in each segmental ganglion of the leech Hirudo medicinalis. While most Rz cells innervate the body wall in their own segment and, by way of axons in the interganglionic connectives, the body wall of adjacent segments, the $R z$ cells in ganglia 5 and $6[R z(5,6)]$ lack interganglionic axons and innervate only the reproductive tissue (Glover and Mason, 1986). Here we describe and quantify the development of differences between $\operatorname{Rz}(5,6)$ and other $R z$ cells in peripheral innervation, neuropilar arborization, and soma size. We filled individual $R z$ cells with Lucifer yellow or HRP in adults and in staged embryos. During the first $\mathbf{7 2} \mathrm{hr}$ of outgrowth of Rz cell processes, the morphology of $\operatorname{Rz}(5,6)$ was indistinguishable from that of other Rz cells. Only after the processes of $\operatorname{Rz}(5,6)$ reached the reproductive tissue did they begin to differ from their segmental homologs. This temporal correlation suggests that these morphological differences arise because of some interaction between $\operatorname{Rz}(5,6)$ and their target tissue.
\end{abstract}

During development and throughout its life, a neuron must use a combination of intrinsic and extrinsic cues to produce and subsequently maintain a particular identity. How each neuron interprets the information from its lineage and its surroundings to produce a unique phenotype is a fundamental question of developmental neurobiology. Segmentally homologous neurons are derived from identical or nearly identical sets of precursors, so that much of the intrinsic information they contain must be the same. Thus, differences between segmental homologs may arise in part from segment-specific extrinsic cues as well as segment-specific intrinsic information. Segmental variation in the morphology and physiology of homologous neurons has been described in several invertebrates (e.g., Larimer et al., 1971; Mittenthal and Wine, 1978; Wilson, 1979; Bate et al., 1981), including the leech (Yau, 1976; Shafer and Calabrese, 1981; Gillon and Wallace, 1984; Johansen et al., 1984; Loer et al.,

\footnotetext{
Received Nov. 18, 1985; revised Jan. 28, 1987; accepted Jan. 29, 1987.

We thank Drs. K. French, W. Harris, W. Thompson, and D. Weisblat for commenting on an early version of this manuscript. We also thank S. Reynolds, S. Furgal and L. Peluffo for technical assistance. This work was supported by NIH Grant NS20746 to W.B.K., NIH Postdoctoral Fellowship NS07684 to J.J., and an NSF predoctoral fellowship to C.M.L.

Correspondence should be addressed to John Jellies, Department of Biology, B-022, University of California, San Diego, La Jolla, CA 92093.

Copyright (C) 1987 Society for Neuroscience $0270-6474 / 87 / 092618-12 \$ 02.00 / 0$
}

1986). Studies on insects (Ghysen et al., 1983; Anderson, 1985) and nematodes (Chalfie et al., 1983) indicate that both internal and environmental information influence the means by which neurons acquire their phenotype. Because they are identifiable throughout their differentiation, Retzius (Rz) cells of the leech provide an opportunity to examine the detailed roles of intrinsic and extrinsic cues in the development of segmental specialization of single neurons.

There are 2 large serotonergic $\mathrm{Rz}$ cells in each segmental ganglion of the leech Hirudo medicinalis. Each cell innervates the body wall of its own segment and, by way of axons in the interganglionic connectives, the body wall of adjacent segments as well. $\mathrm{Rz}$ cell firing causes mucus release from the skin (Lent, 1973), an increased tendency for the nerve cord to produce the swimming motor program (Willard, 1981), and increased contraction and relaxation rates of body wall muscle (Mason et al., 1979; Mason and Kristan, 1982) via the release of serotonin. The $\mathrm{Rz}$ cells in ganglia 5 and $6[\mathrm{Rz}(5,6)]$ do not innervate the body wall, but instead innervate the male and female reproductive organs that are found in midbody segments 5 and 6 . These cells may be involved in the function of the sex organs during reproduction (Zipser, 1979). Unlike other $\mathrm{Rz}$ cells, $\mathrm{Rz}(5,6)$ are not excited by the swimming motor program (Glover, 1984) or by the pressure mechanosensory neurons (G. Wittenberg and C. Loer, unpublished observations). Despite differences in peripheral innervation and other characteristics between $\operatorname{Rz}(5,6)$ and "standard" Rz cells in adult leeches, the early development of $\mathrm{Rz}$ cells is the same in all segments. Differences in $\mathrm{Rz}(5,6)$ arise only after their processes have reached the developing reproductive tissue. The development and subsequent loss of interganglionic connective axons of $\mathrm{Rz}(5,6)$ have been briefly described (Glover and Mason, 1986). Here, we describe and quantify how $\mathrm{Rz}(5,6)$ become different in three other morphological features: peripheral processes, soma size, and neuropilar arborization. We also describe the development of the reproductive tissue and its relationship to the outgrowth of $\mathrm{Rz}$ cell processes. As a working hypothesis, we propose that some interaction with the developing reproductive tissue is necessary for the unique development of $\mathrm{Rz}(5,6)$. Experiments addressing this hypothesis are presented in the following paper (Loer et al., 1987).

\section{Materials and Methods}

Animals. Embryos of Hirudo medicinalis were obtained from a laboratory breeding colony. Hirudo were maintained in water at $15^{\circ} \mathrm{C} \mathrm{except}$ for breeding and feeding. Adults of breeding size ( $10 \mathrm{gm}$ or greater) were kept at $15^{\circ} \mathrm{C}$ for 2 weeks after feeding, then moved to room temperature $\left(22-23^{\circ} \mathrm{C}\right)$ for 2 weeks. Following this, the animals were placed, in groups of 8 , into slanted aquaria with moist green moss (from severeral suppliers, e.g., L. \& L. Nursery Supply, Inc., Chino, CA) and water (5-7 
cm maximal depth) at room temperature, where they remained for the next 16 weeks. The moss was checked for cocoons $3 \mathrm{~d}$ a week. The age of a cocoon was estimated by its color and texture, which changes during the first few days after laying.

Each group of 8 individuals produced $20-40$ cocoons during the 16 weeks in moss. Embryos were routinely removed from the cocoon after 8-10 d of development and kept in spring water (Silver Springs, with $73 \mu \mathrm{M} \mathrm{MgCl}_{2}$ and $63 \mu \mathrm{M} \mathrm{CaCl}_{2}$ added). Neither the rate of development nor the survival of the isolated embryos differ noticeably from that of embryos left in cocoons. Animals were raised at room temperature $\left(22^{\circ} \mathrm{C}\right)$ and staged in days of development as previously described (Fernandez and Stent, 1982).

Segmental ganglia were numbered within the midbody as previously described (Kristan et al., 1974). The first 4 ganglia fuse to form the subesophageal mass and are not counted in this scheme.

Staining the developing reproductive tissue. The developing reproductive tissue could be seen as clumps of tissue after 9 or $10 \mathrm{~d}$ of development of using reflected light and a dissecting microscope. In order to study the earlier development of this tissue, we stained staged embryos with Mayer's Haematoxylin (Sigma). Embryos in IIirudo saline (Muller et al., 1981) were dissected and then fixed in a 25\% solution of concentrated formaldehyde (Mallinckrodt) for 10-15 min, then rinsed in running water for 5-10 min. Fixed preparations were stained with $0.1 \%$ Haematoxylin at room temperature for $15-25 \mathrm{~min}$ and rinsed in running water for an additional $10-20 \mathrm{~min}$. These preparations were immediately dehydrated in a standard ethanol series, cleared in either methyl salicylate or xylene, and mounted in Permount. Whole mounts were photographed and drawn with a camera lucida. Particular attention was given to tracing important landmarks such as the ganglionic primordia, nephridiopores, and germinal plate boundary.

Examination of peripheral processes. We used the fluorescent dye Lucifer yellow (Sigma) to stain individual $\mathrm{Rz}$ cells at various stages of development. The animals were prepared for intracellular injections as previously described (Kuwada and Kramcr, 1983), except that embryos prepared for injection of Lucifer yellow were briefly fixed (15-30 sec) in $1 \%$ paraformaldehyde in $0.1 \mathrm{M}$ phosphate buffer $(\mathrm{pH} 7.4)$ following the dissection. This short fixation reduced movements of the embryo and thereby assisted in maintaining penetrations and filling the cells with dye.

Micropipettes ( $200-400 \mathrm{M} \Omega$ ) were filled with either 3,5 , or $7 \%$ aqueous Lucifer yellow in the tips and $1 \mathrm{~m}$ lithium chloride in the shanks (Stewart, 1978). The lower concentrations seemed to work better in very young (7-8 d) embryos. Neurons were filled by passing hyperpolarizing direct current $(0.1-2.0 \mathrm{nA})$ through the microelectrode for $1-3 \mathrm{~min}$. The whole embryo was then fixed in cold $4 \%$ paraformaldehyde in $0.1 \mathrm{M}$ phosphate buffer (pH 7.4) for $30 \mathrm{~min}$ to $1 \mathrm{hr}$ and rinsed several times in PBS. It was then dehydrated in a standard ethanol series and cleared in methyl salicylate. Whole mounts in methyl salicylate were cxamincd on a Zciss microscope with epifluorescence (Zeiss filter unit 48-77-06). Filled cells were photographed and also drawn with a camera lucida.

Examination of central processes. In an effort to examine the arborizations of $\mathrm{Rz}$ cells within the neuropil, we employed HRP as an intracellular marker because the brightness of the Lucifer-filled somata often obscured this region. In addition, since the fluorescent dye faded after continuous exposure to UV radiation, it was not suitable for extended examination of fine processes.

Embryos for HRP injections were prepared as described for Lucifer yellow, except that they were not prefixed. All injections were carried out on animals narcotized in cold $8 \%$ ethanol in saline. The enzyme was prepared as either 3 or $5 \%$ with $2 \%$ fast green (final concentrations) in $0.2 \mathrm{M}$ potassium chloride. The microelectrodes were beveled on a dry abrasive (No. 6775 E54, Arthur H. Thomas Co., Philadelphia, PA) and had impedances of 150-250 M . Somata were injected by applying several pressure pulses (10-25 p.s.i.) to the back of the microelectrode until the cell bodies turned visibly blue-green and/or showed about a $30 \%$ increase in diameter. The embryos were then pinned loosely in L- 15 medium and left for $1-2 \mathrm{hr}$ at room temperature to allow the HRP to fill the cell completely. Subsequently, the embryo was again narcotized, stretched, and fixed for $30 \mathrm{~min}$ to $1 \mathrm{hr}$ in cold $2 \%$ glutaraldehyde/ $2 \%$ paraformaldehyde in $0.1 \mathrm{~m}$ phosphate buffer ( $\mathrm{pH} 7.4$ ). All preparations were developed with $\mathrm{H}_{2} \mathrm{O}_{2}$ in $0.5 \mathrm{mg} / \mathrm{ml}$ diaminobenzidine tetrahydrochloride (DAB; Litton Bionetics) in $0.1 \mathrm{~m}$ Tris buffer ( $\mathrm{pH} \mathrm{7.4)}$ with cohalt intensification (Gillon and Wallace, 1984), dehydrated, cleared, and mounted in Permount.

To quantify the density of neuropilar arborization (Weeks and Tru- man, 1985), we first drew the cells with a camera lucida. Tracing paper with millimeter squares was placed over the drawing and processes were scored by filling in every square that contained any part of a central process (Fig. 8, $A, B$ ). Each millimeter on the drawing represented 2.5 $\mu \mathrm{m}$ on the ganglion. Processes extending beyond the ganglionic border (i.e., peripheral or interganglionic processes) were not scored. Process density was then defined as the number of filled squares divided by the total number of squares enclosed by the ganglionic margin (exclusive of the squares occupied by the cell body).

Staining with serotonin antiserum. Antibody staining was performed in a manner similar to that of Glover and Mason (1986). Live embryos were soaked in $10^{-4} \mathrm{M} 5-\mathrm{HT}$ in spring water for $2-4 \mathrm{hr}$ before dissection to saturate the uptake system of the serotonin-containing neurons. After dissection, the embryos were fixed overnight at $4{ }^{\circ} \mathrm{C}$ in either fresh $4 \%$ paraformaldehyde in $0.1 \mathrm{~m}$ phosphate buffer ( $\mathrm{pH} \mathrm{7.4)}$ or in fresh $1.5 \%$ picric acid-4\% formaldehyde (PAF) (Stefanini et al., 1967). Fixation with PAF gave slightly better results. After several rinses in PBS, embryos were incubated overnight at room temperature in 1:1000 rabbit 5 -HT antibody (Immunotech) in PBS with $1 \%$ goat serum, 1\% BSA, $2 \%$ Triton X-100, and $0.1 \%$ sodium azide (all from Sigma). Embryos were subsequently rinsed for $2 \mathrm{hr}$ in PBS and then incubated overnight at room temperature with 1:1000 HRP-conjugated goat anti-rabbit IgG (Cappel) in PBS with $4 \%$ goat serum, $1 \%$ BSA, and $2 \%$ Triton X-100. Embryos were rinsed in PBS and transferred to $0.1 \mathrm{~m}$ Tris buffer $(\mathrm{pH}$ 7.4). The HRP reaction was carried out in $0.5 \mathrm{mg} / \mathrm{ml} \mathrm{DAB}$ in Tris buffer with about $0.1 \%$ hydrogen peroxide. For viewing, embryos were dehydrated in a graded ethanol series, cleared in xylene, and mounted on slides in Permount.

Measurements of soma size. $\mathrm{Rz}$ soma size was expressed as an area treating the cell body as an ellipse. The cells were viewed from the ventral surface of the ganglion, and a major $\theta_{1}$ and minor $\theta_{2}$ diameter were measured with an ocular micrometer. The area was calculated as $(1 / 4) \pi \theta_{1} \theta_{2}$. For unambiguous identification at early stages, $\mathrm{Rz}$ cells in staged embryos were measured in fixed and mounted preparations stained with the serotonin antiserum. Despite fixation and dehydration of these preparations, the $\mathrm{Rz}$ cells were comparable in size to those of living embryos. $\mathrm{Rz}$ cells in adult Hirudo $(2-3 \mathrm{gm})$ were measured in wetmounted living ganglia.

\section{Results}

Most Rz cells project their peripheral processes into the body wall in their segment of origin to establish "primary" innervation fields. They also send axons into the rostral and caudal interganglionic connectives and out the roots of adjacent ganglia, establishing "secondary" fields in the body wall of those segments; these innervation patterns are evident as early as at 12 $\mathrm{d}$ of development (Fig. 1). At this stage, the patterns of primary and secondary innervation of standard Rz cells are quite similar. However, the innervation patterns of $\operatorname{Rz}(5,6)$ differ from those of the $\mathrm{Rz}$ cells in the remaining 19 midbody ganglia. The peripheral processes of these neurons are associated exclusively with the reproductive structures: $R z(5)$ innervates only the male tissue, whereas $\mathrm{Rz}(6)$ innervates both male and female tissue.

The $\mathrm{Rz}$ cells in the fifth and sixth ganglia also lack interganglionic processes (Glover and Mason, 1986; and Fig. 1) and consequently they do not establish secondary innervation fields in adjacent segments. The secondary innervation from $\mathrm{Rz}(4)$ (not shown) and $\operatorname{Rz}(7)$ (Fig. 1) was normal and provided the serotonergic innervation of the body wall in midbody segments 5 and 6 . Secondary branches from $\mathrm{Rz}(7)$ apparently provided none of the serotonergic innervation of the female tissue, while $\mathrm{Rz}(4)$ did project a minor branch into the male tissuc in the 2 preparations in which dye traveled far enough to reveal its secondary branching. Thus, in advanced embryos and adults, $\mathrm{Rz}(5,6)$ devote their entire innervation to the reproductive structures, in striking contrast to their segmental homologs.

It was also apparent that the somata of $\mathrm{Rz}(5,6)$ were smaller than those in other segments, and that there were differences in 
A

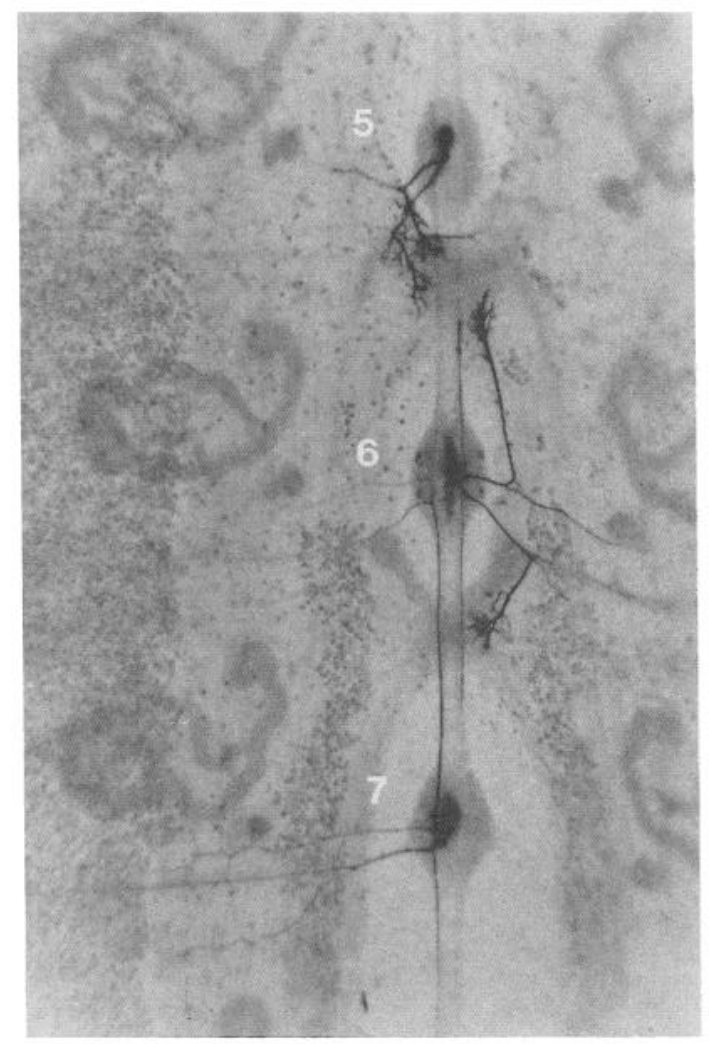

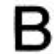

Figure 1. Segmental differences in peripheral branching patterns of $\mathrm{Rz}$ cells. A, A negative photograph of $\mathrm{Rz}$ cells in a day 12 embryo filled with the fluorescent dye Lucifer yellow. One of the pair of neurons was filled, on alternating sides, in segments 5,6 , and 7 . Notice that $\mathrm{Rz}(5)$ and $\mathrm{Rz}(6)$ have begun to lose their interganglionic axons at this stage (Glover and Mason, 1986), whereas $\mathrm{Rz}(7)$ has already established secondary innervation in adjacent segments, as indicated here for segment 6 . The "standard" innervation of the body wall by $\mathrm{Rz}$ cells is shown by $\mathrm{Rz}(7)$. B, Camera lucida drawing of the neurons in $A$. Because all processes are shown, regardless of focal plane, the relationship of neuronal processes to various landmarks is seen more clearly. Many $\mathrm{Rz}(7)$ processes project beyond the nephridiopore in its segment of origin, as well as in segment 6 , while $\mathrm{Rz}(5)$ and $\mathrm{Rz}(6)$ have only rudimentary laterally directed branches at this stage. Calibration bar, $100 \mu \mathrm{m}$.

neuropilar arborization as well (Figs. 6-8). This paper will document the development of such segmental differences in homologous Rz cells. Because these segmental differences are associated with the development of the reproductive organs, we will first describe the basic structure and morphogenesis of these target structures.

\section{Development of the reproductive structures}

An adult leech contains both male and female gonads and copulatory organs (Fig. 2). Both male and female segments have a genital pore (not seen here) located on the ventral midline one annulus posterior to the segmental ganglion. In the male segment (5), the genital pore opens into the penis sheath. A homologous chamber in the female segment (6) is called the vagina. Two arms extend laterally from the end of each of these chambers. In segment 6 these arms are oviducts leading to the ovaries. In segment 5 these arms are contractile tubules leading into the epididymus. This tube forms an arc that curves posteriorly to join with the vas deferens, which in turn runs posteriorly to connect with the sperm sacs in midbody segments 7-15 (or occasionally 16). Whole mounts of adult reproductive organs stained with an antiserum to serotonin revealed dense and var- icose innervation of the epididymus and ejaculatory ducts, with a somewhat lighter innervation of the penis sheath and vas deferens. In the female segment, serotonin-containing processes heavily innervate the vagina and oviducts (Fig. $2 A$ ). This pattern is already established in the late (24-d-old) embryo (Fig. $2 B$ ).

These reproductive structures arise very early during embryogenesis. The primordia of both male and female reproductive tissue were apparent in 7-d-old embryos stained with Mayer's Haematoxylin (Fig. 3). This technique consistently stained clumps of cells present in segments 5 and 6 but absent in other segments. We consider these early, darkly staining clumps to be the reproductive primordia since, at progressively later stages, the densely stained tissue in this area gradually took the form of reproductive tissue. At this stage, the presumptive reproductive organs were seen as thickenings of tissue, probably of mesodermal origin (M. Shankland, personal communication), between the nephridiopores and lateral to the ganglionic primordia. Over the next $48 \mathrm{hr}$ the tissue increased in size and moved posterior and medial to the ganglia. It also moved through the muscular layer to a position just below the epithelium (K. French and S. Furgal, personal communication). During day 10 of development, the primordia from both sides met at the future 
A

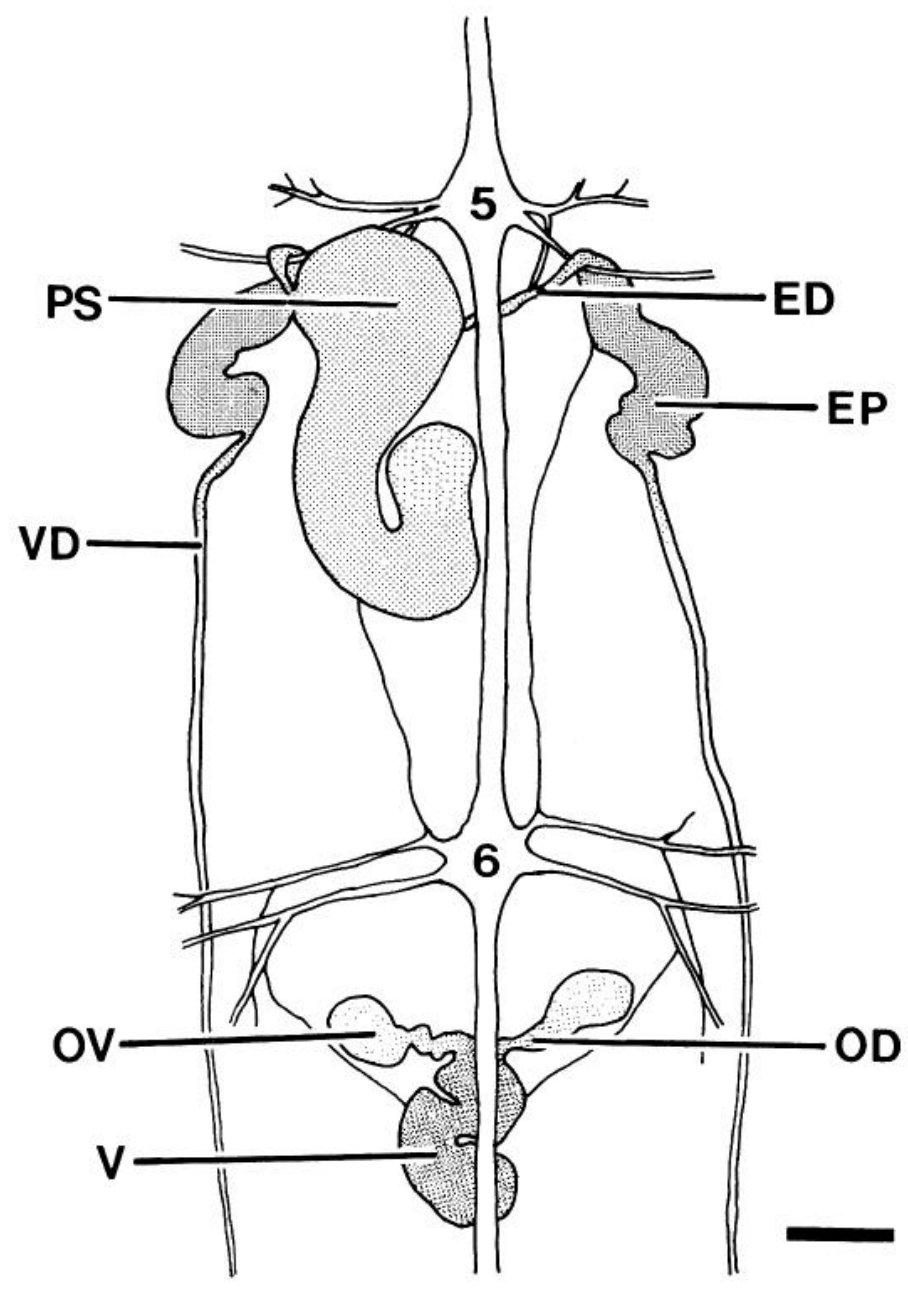

B

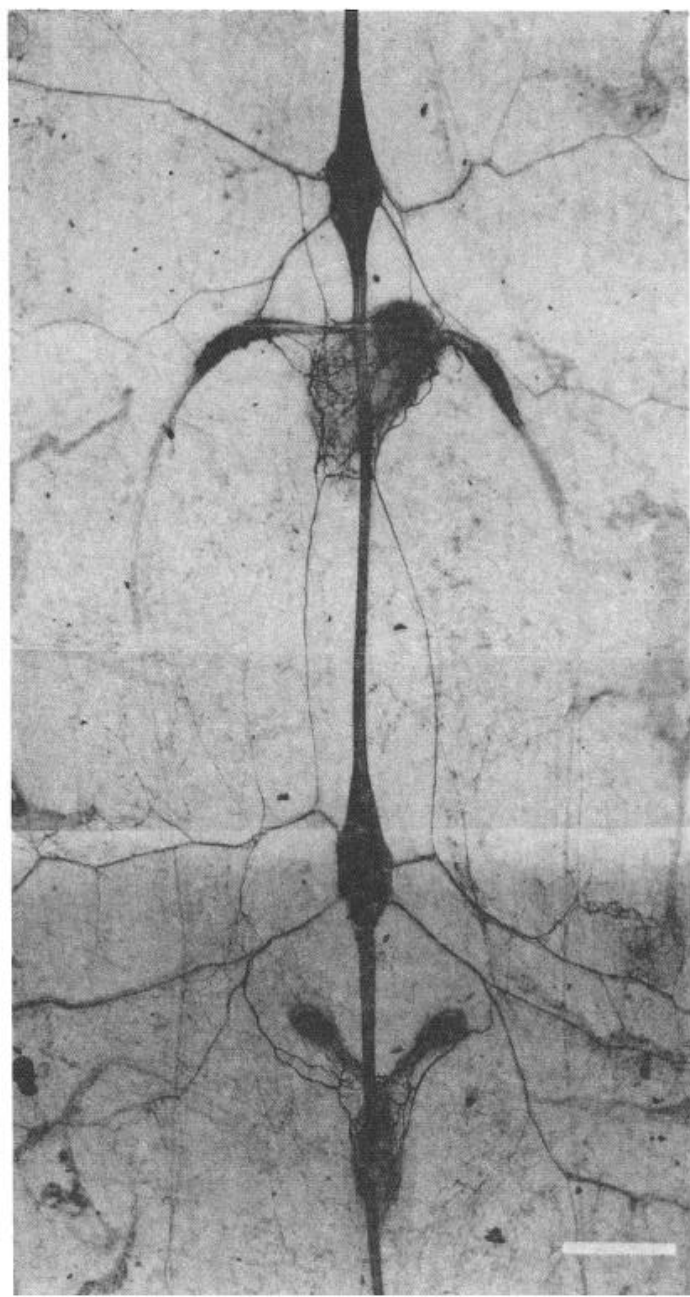

Figure 2. Mature structure of the reproductive organs and their serotonergic innervation. $A$, Drawing of dorsal view of reproductive organs, ganglia, and nerves in midbody segments 5 and 6 of an adult leech (2-3 gm). Ganglia 5 and 6 are numbered. Other abbreviations: $P S$, penis sheath; $E D$, ejaculatory duct; $E P$, epididymus; $V D$, vas deferens; $O V$, ovary; $O D$, oviduct; $V$, vagina. Differences in stippling indicate the location and relative density of serotonin-containing processes in the reproductive organs. Anterior is up. Calibration bar, $1 \mathrm{~mm}$. $B$, Photograph of a late embryo ( $24 \mathrm{~d}$ old) stained with serotonin antiserum and HRP-conjugated secondary antibody, in the same orientation as in $A$. Note the heavy serotonergic innervation of the reproductive organs. Calibration bar, $100 \mu \mathrm{m}$.

ventral midline just caudal to the fifth and sixth ganglia. After meeting, midline tissue thickened and the gonopores were formed. During this same period the primordia formed the lateral ejaculatory ducts of the male, and the oviducts of the female. In addition, the ovaries became apparent as swellings on the lateral ends of the oviducts in segment 6 during day 10 .

\section{Development of $R z$ peripheral innervation patterns}

During day 8 , all $\mathrm{Rz}$ cells in anterior ganglia initiate the growth of both interganglionic and peripherally directed axons (Glover, 1984). Except for a rostrocaudal gradient of development, there are no other observable segmental differences in the early growth of either central (Glover and Mason, 1986) or peripheral axons. By filling individual $\mathrm{Rz}$ cells with Lucifer dye at various stages and reconstructing their morphologies, we have delineated the major sequence of events involved in the formation of segmental differences in primary innervation patterns (Fig. 4).
There are at least 3 phases in the growth of peripheral axons in $\mathrm{Rz}$ cells. In the first phase, all $\mathrm{Rz}$ cells were found to grow their processes along identical trajectories, leaving the ganglion during day 8 (Fig. $4 A$ ) in both the anterior and posterior nerve roots. Lateral growth was the same in all segments through most of day 9 , along pathways that were similar to those taken earlier by the mechanosensory neurons. For example, the $\mathrm{P}$ cells are among the earliest cells to grow into the periphery in the leech Haementeria (Kuwada and Kramer, 1983; Kuwada, 1985). In Hirudo, P cells also develop early, having well-established primary innervation fields at a stage when the $\mathrm{Rz}$ cells are just exiting the ganglion (not shown).

The second phase of growth began late in day 9, when the laterally directed axons of $\mathrm{Rz}(5,6)$ appeared to meet the medially directed reproductive tissue primordia (Fig. $4 B$ ). At this time, $\mathrm{Rz}(5,6)$ ceased lateral growth and began to grow with and along the reproductive tissue toward the midline (Fig. 4C). Subse- 

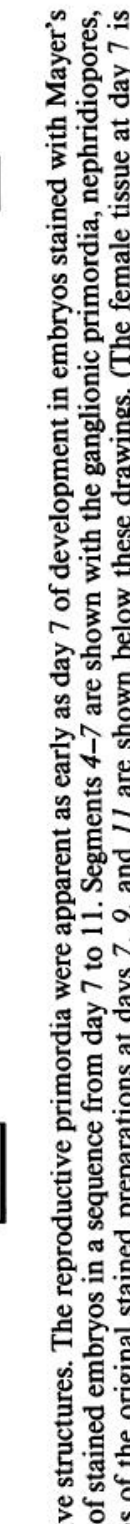
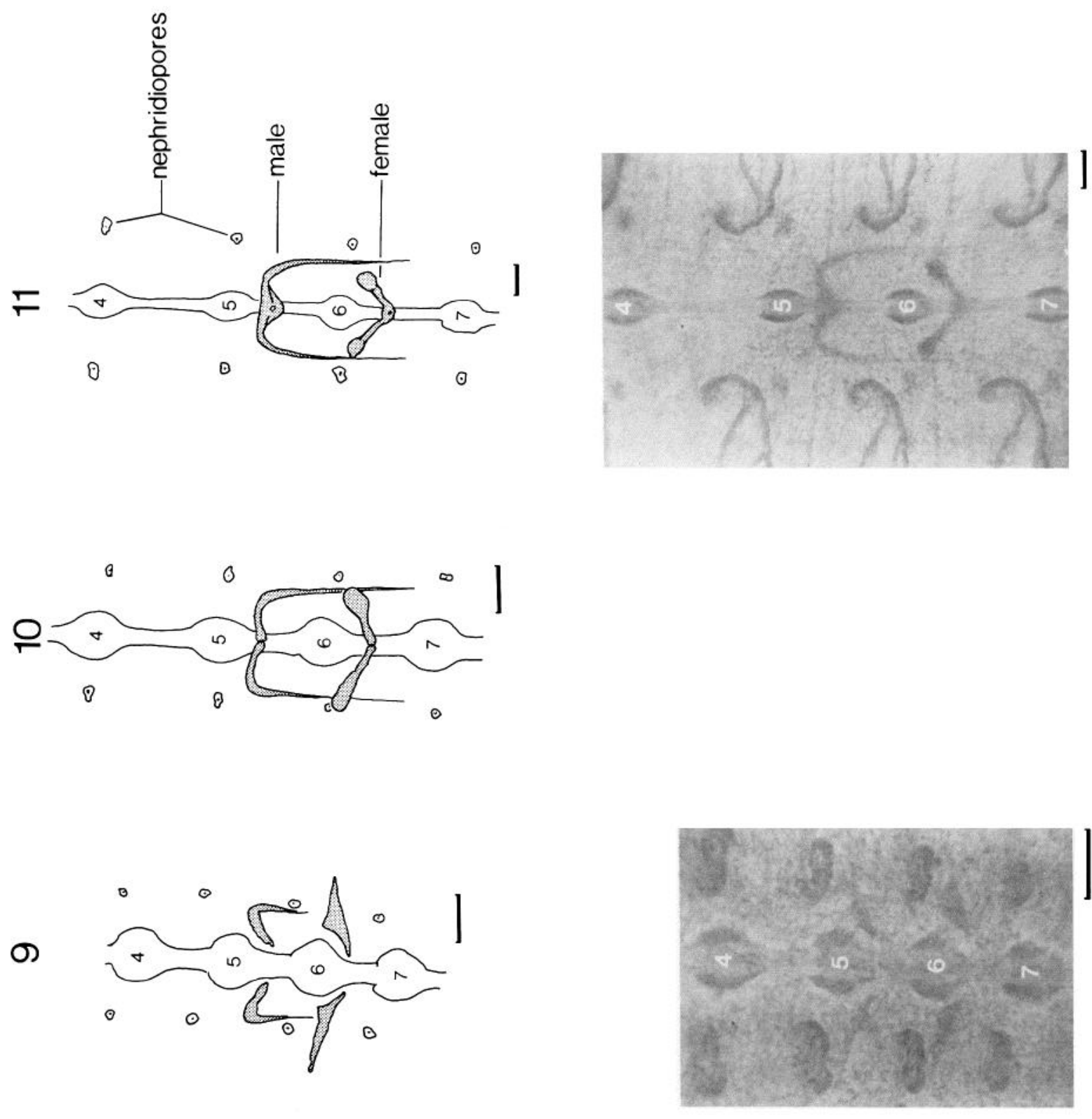

a

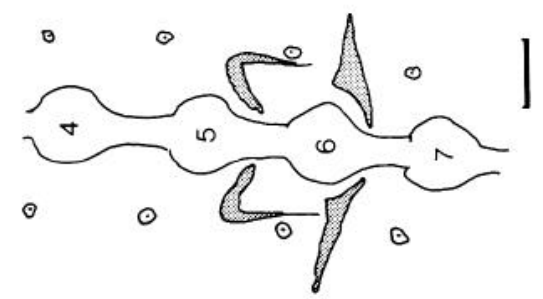

$\infty \underbrace{0}_{0} \underbrace{0}_{00} \underbrace{0}_{0}$

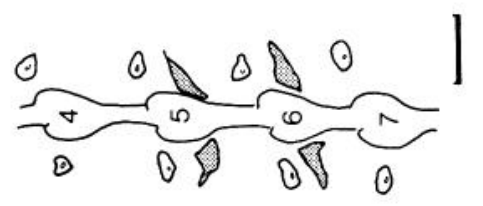

$N$
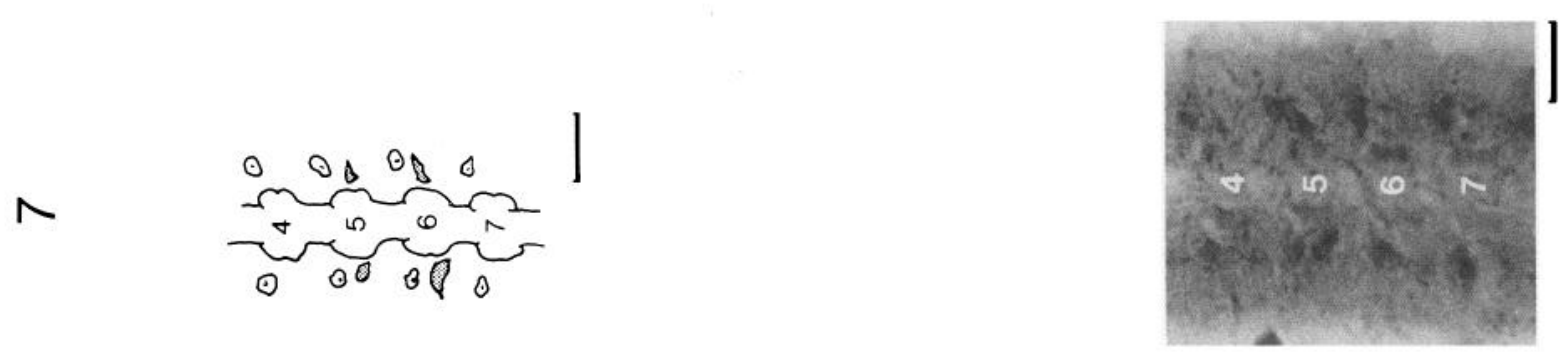


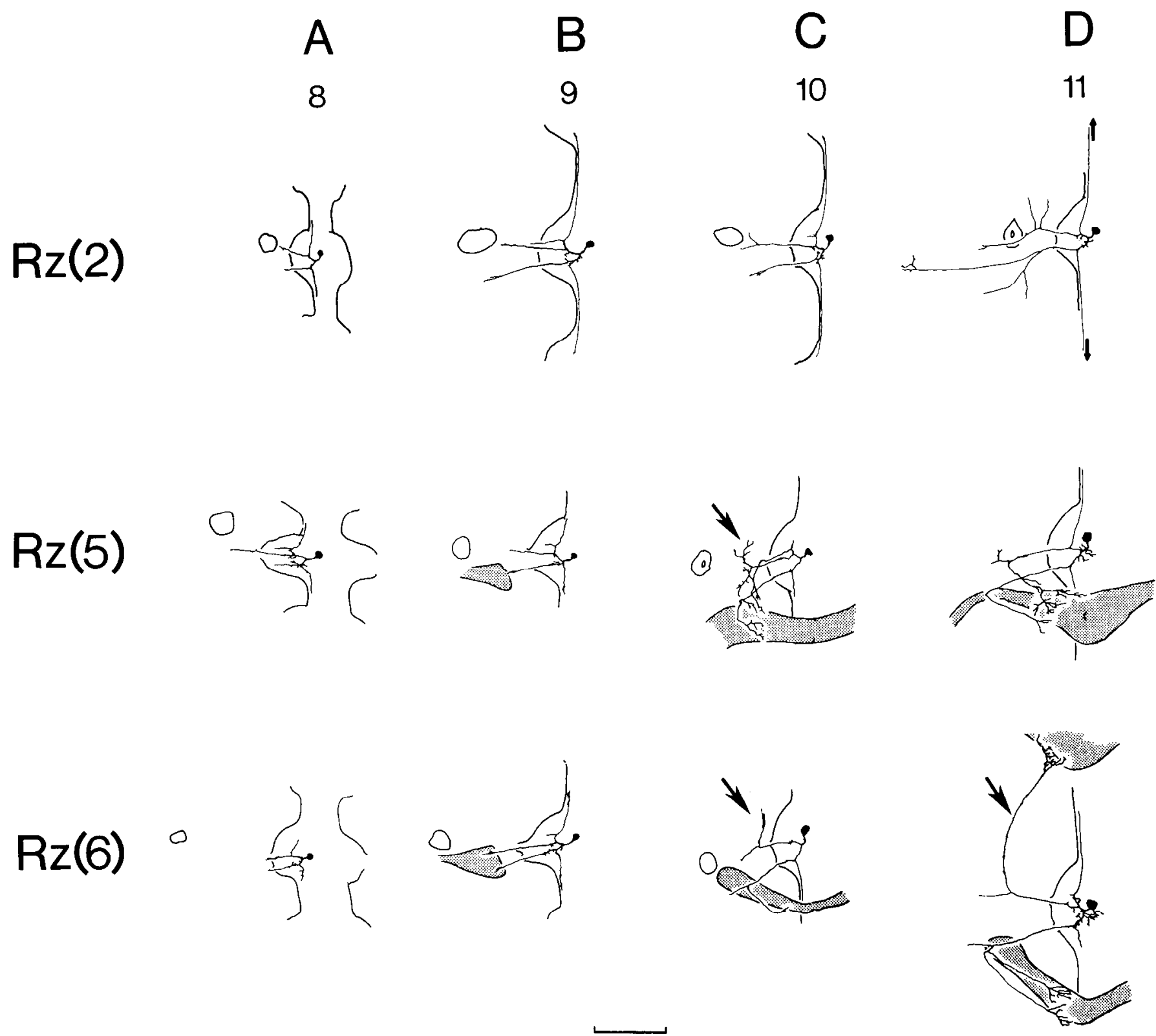

Figure 4. The developmental sequence involved in forming the distinctive innervation patterns of $\mathrm{Rz}$ cells. Camera lucida drawings were made of Lucifer yellow-filled $\mathrm{Rz}$ cells from segments 2,5 , and 6 at $(A) 8 \mathrm{~d},(B) 9 \mathrm{~d},(C) 10 \mathrm{~d}$, and $(D) 11 \mathrm{~d}$ of development. The rostrally and caudally directed arrows on $\operatorname{Rz}(2)(D)$ indicate that the central processes extended beyond the drawing into adjacent segments. $C$ and $D$, Large arrows indicate the anteriorly directed branch from $\mathrm{Rz}(5,6)$ (see text). Anterior is up, ventral view. Calibration bar, $100 \mu \mathrm{m}$.

quently, many branches arose from those processes, most of which also grew along the reproductive tissue toward the midline.

The third phase of growth was marked by the initiation of a secondary, rostrally directed process from the primary anterior process in both $\mathrm{Rz}(5)$ and $\mathrm{Rz}(6)$ (arrows in Fig. 4, C, D). In contrast to most of the other secondary processes, these were directed away from the reproductive tissue in their own segment (Fig. 4C). From segment 6, this process grew rostrally over the subsequent $24 \mathrm{hr}$ into segment 5 . It eventually provided significant innervation to the male tissue in segment 5 (Figs. $4 D$, 1). The anteriorly directed process from $\mathrm{Rz}(5)$ ceased growing, however, within $24 \mathrm{hr}$ after it was initiated (Fig. $4 D$ ). During this time, a caudally directed process was initiated at about the same location as the first rostrally directed one. The caudally directed process persisted to innervate the male tissue heavily (Figs. $4 D, 1)$. Thus, $\mathrm{Rz}(5)$ came to innervate only male tissue, while $\mathrm{Rz}(6)$ retained the rostrally directed secondary branch to innervate the male as well as female tissue.

In addition to making these qualitative observations, we measured the time course of primary process outgrowth in the periphery. The relative lengths of the laterally directed axons (see Materials and Methods and Fig. $5 A$ ) were measured in animals at different stages $(n=112)$. The rostrocaudal gradient in the development of these processes can be seen by comparing the process lengths of rostral $[\mathrm{Rz}(2-4)]$ to those of caudal $[\mathrm{Rz}(7-$ 12)] segments for both anterior (Fig. 5B) and posterior (Fig. 5C) processes. This gradient was very apparent at early stages (7-8 d), but disappeared as the axons acquired their mature patterns (after 10-11 d). Both the anterior and posterior processes of all 


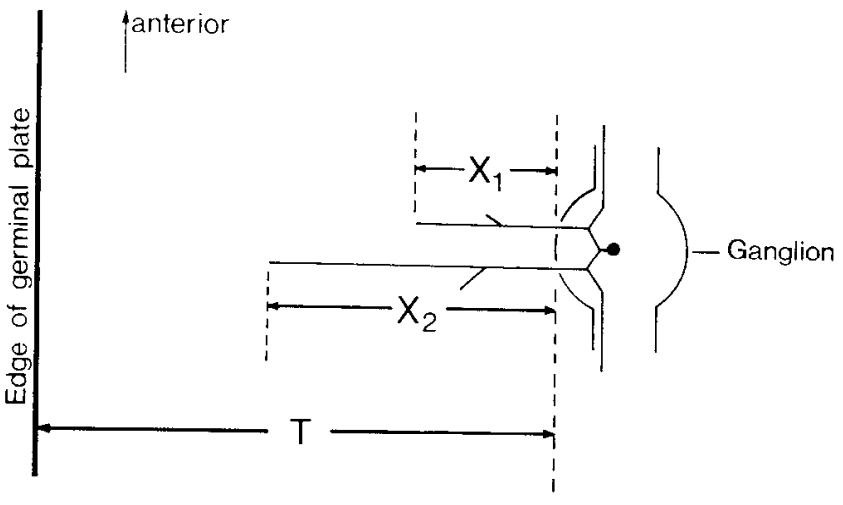

Figure 5. Time course of the lateral extension of $\mathrm{Rz}$ cell primary peripheral axons. $A$, Distance ratios of laterally directed processes were calculated as shown here and as discussed in Materials and Methods. Data are presented in histograms showing the relative growth of both the most anterior $(B)$ and posterior $(C)$ axons. The hatched bars represent $\mathrm{Rz}(2-4)$, open bars $\operatorname{Rz}(5,6)$, and black bars $\mathrm{Rz}(7-12)$. The data were grouped into 3 time bins, as indicated below each. The negative ratios in the 7-8 d bins indicate that most of the processes in posterior segments had not yet exited the ganglion at these early stages (" 0 " is the edge of the ganglion). After day $9, \mathrm{Rz}(5)$ and $\mathrm{Rz}(6)$ showed no further lateral extension, while the standard $\mathrm{Rz}$ cells extended both anterior $(B)$ and posterior $(C)$ processes into the lateral body wall. The differences between $\operatorname{Rz}(5,6)$ and all other Rz cells at days 10 and 11 were statistically significant $(p<0.001$; Student's $t$ test) for both anterior and posterior processes. Error bars denote \pm SEM.

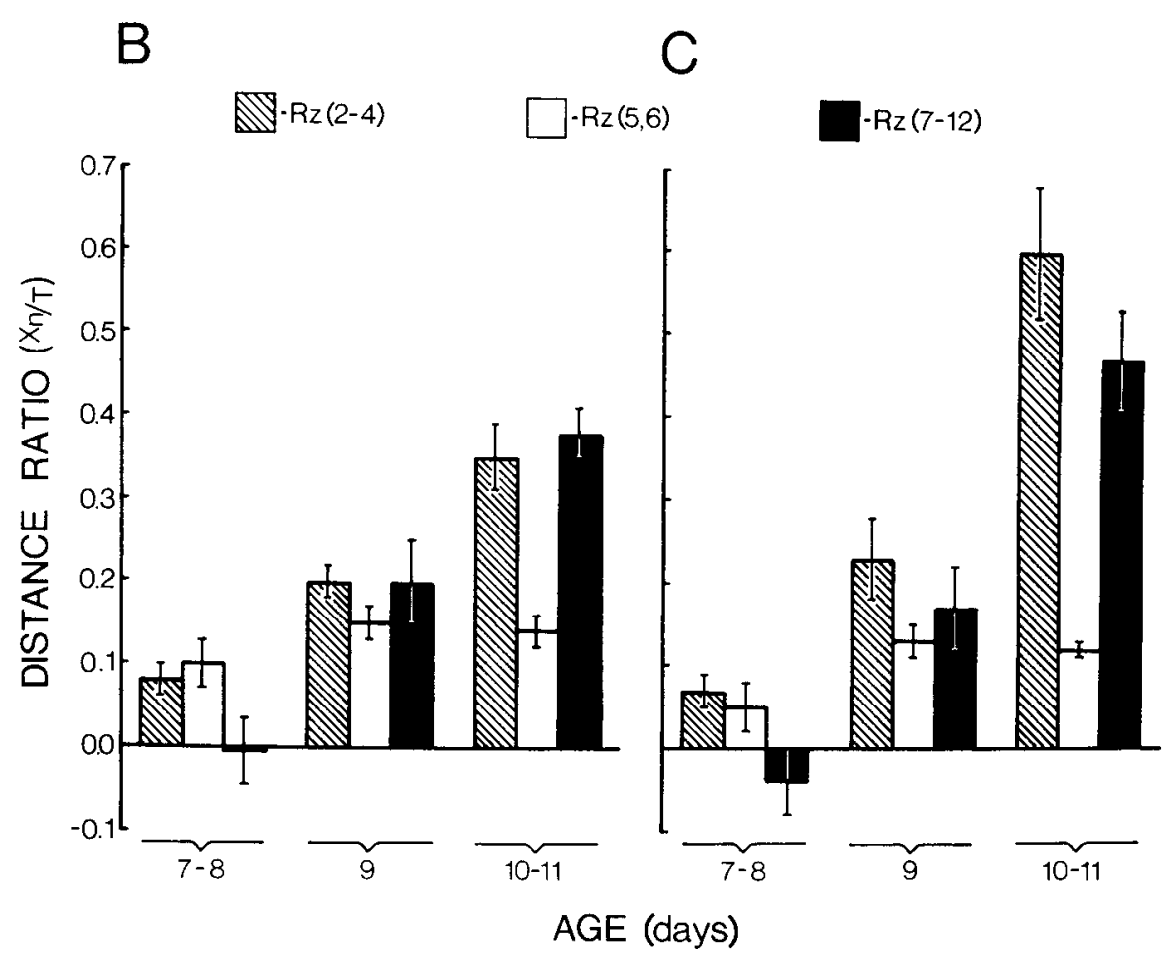

Rz cells extended laterally to the same degree for approximately the first $72 \mathrm{hr}$ of growth, from day 7-9. After day 9 of development, $\operatorname{Rz}(5,6)$ completely ceased relative lateral growth, while cells in all other midbody ganglia (2-4 and 7-12) continued to extend laterally.

\section{Development of segmental differences in soma size}

$\mathrm{Rz}$ cells are identifiable not only because of their characteristic central location, but also because their somata are among the largest in the CNS. The somata of the mature $\mathrm{Rz}(5,6)$ are, however, considerably smaller than their segmental homologs (Fig. $6 A$ ). At earlier stages of development (Fig. 6B), size differences were not apparent. We measured $\mathrm{Rz}$ soma areas (see Materials and Methods) during several different stages of development (Fig. 6C) and found that these differences were apparent by day 12 of development. During about 2 weeks of development (from days 9.5-10 to 23-24), the somata of $\mathrm{Rz}$ cells in the standard midbody segments increased in area about 10 -fold, while those in segments 5 and 6 increased only about 3-fold. By days 2324 , the somata of $\mathrm{Rz}(3,4,7,8)$ were $31.3 \pm 0.5 \mu \mathrm{m}$ in diameter, while those of $\operatorname{Rz}(5,6)$ averaged only $18.9 \pm 0.5 \mu \mathrm{m}$ (all measurements are \pm SEM). This relative difference was maintained in the adult. In 2-3 gm leeches, the somata of $\operatorname{Rz}(3,4,7,8)$ averaged $90.8 \pm 0.7 \mu \mathrm{m}$ in diameter and $\mathrm{Rz}(5,6)$ averaged $59.9 \pm$ $1.6 \mu \mathrm{m}$.

\section{Development of segmental differences in neuropilar arborization}

When standard Rz cells were filled with HRP and viewed in whole mount (Fig. $7 B$ ), a profusion of processes filled the ganglionic interior, primarily ipsilateral to the cell body. When $\operatorname{Rz}(5,6)$ wcre cxamincd in a comparable fashion (Fig. $7 A$ ), there was a consistent paucity of central processes. The processes of $R z(5,6)$ covered about the same general extent of the ipsilateral 
$\mathrm{A}_{1}$

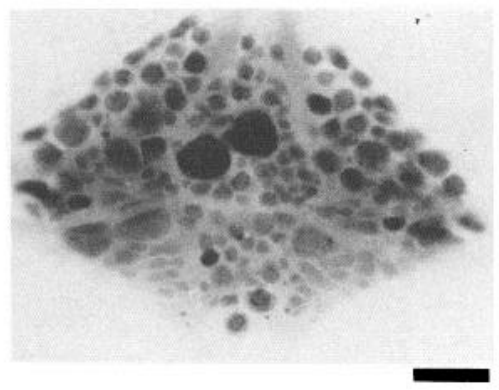

2

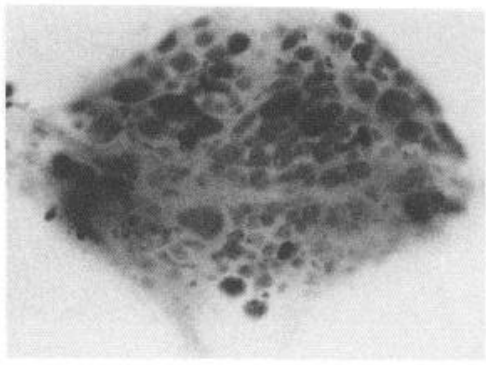

$\mathbf{B}_{1}$

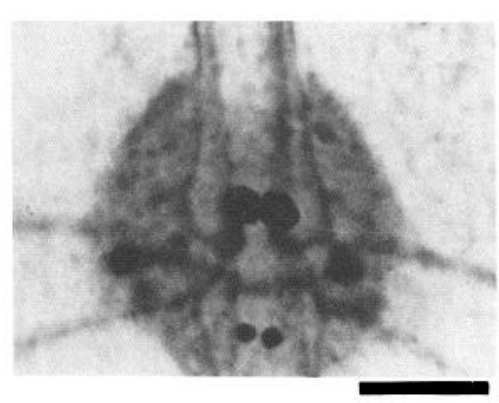

2
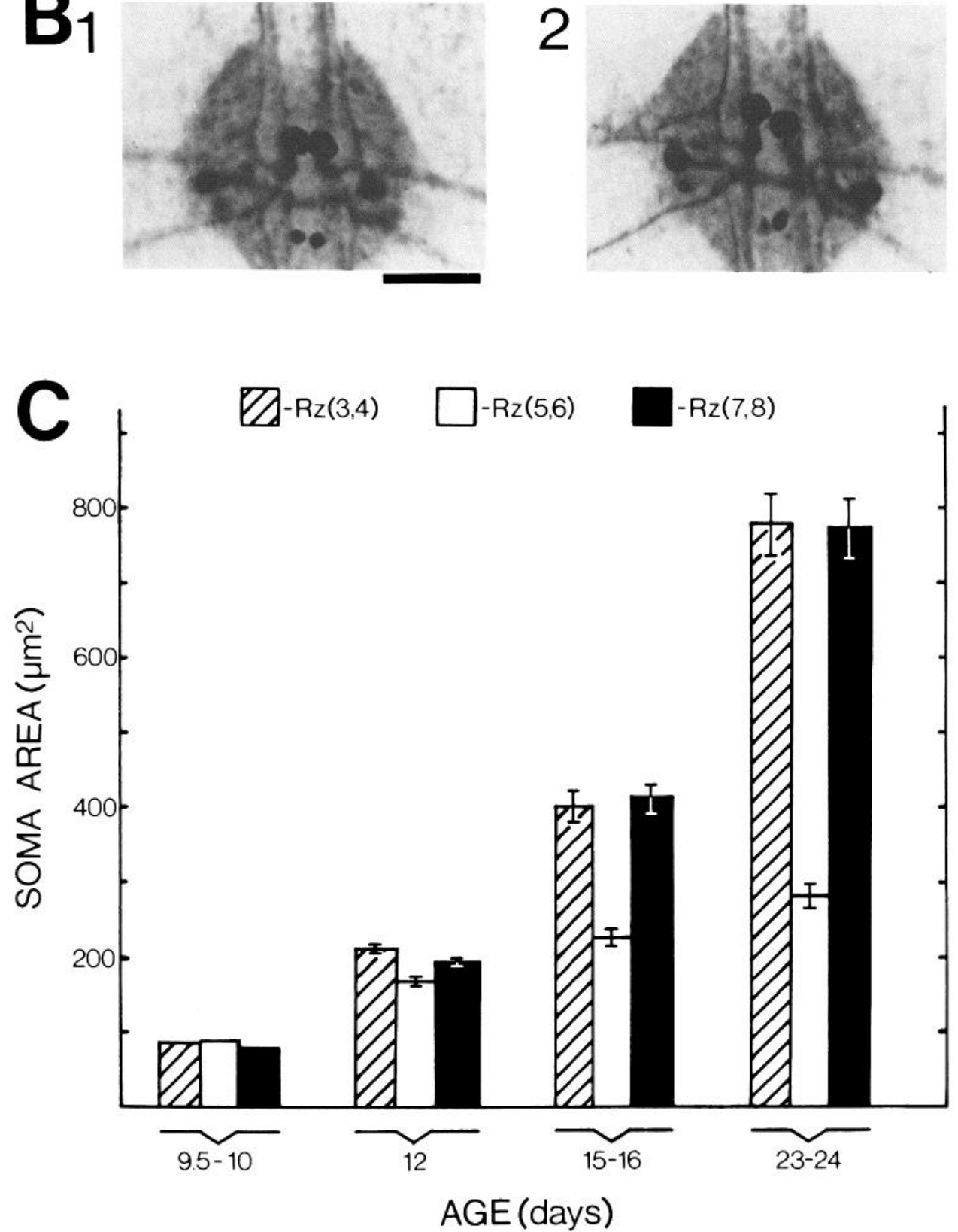

Figure 6. Segmental differences in soma size. $A$, Photographs of the ventral surface of adult ganglia $7(I)$ and 5 (2) stained with methylene blue. Rz cells are the larger, more darkly staining cells in the center of the ganglion. Anterior is up. Calibration bar, $100 \mu \mathrm{m}, B$, Tenday-old ganglia 7 (1) and 5 (2) stained with serotonin antiserum and HRPconjugated secondary antibody. Calibration bar, $50 \mu \mathrm{m}$. $C$, Development of segmental differences in soma size. Histograms of mean soma area \pm SEM (see Materials and Methods) of $\mathrm{Rz}(3,4)$ (hatched bars), $\mathrm{Rz}(5,6)$ (open bars), and $\mathrm{Rz}(7,8)$ (black bars) at days $9.5-10,12$, 15-16 and 23-24. The SEMs at day 9.510 were too small to be indicated. At day $12, \operatorname{Rz}(5,6)$ were significantly smaller than either $\mathrm{Rz}(3,4)$ or $\mathrm{Rz}(7,8)$ $(p<0.01$; Student's $t$ test). This difference was more pronounced at days 15 16 and 23-24 $(p<0.001)$. neuropil, but the density of the minor processes was much less than in the other segments.

To quantify the time course of the development of these central processes, we measured the neuropilar density (see Materials and Methods) of 55 filled cells. As with the other characteristics analyzed in this paper, the neuropilar density of all $\mathrm{Rz}$ cells was uniform at earlier stages of development. But after 14-16 d of development, the rate at which $\operatorname{Rz}(5,6)$ elaborated central pro- 
$\mathrm{A}_{1}$

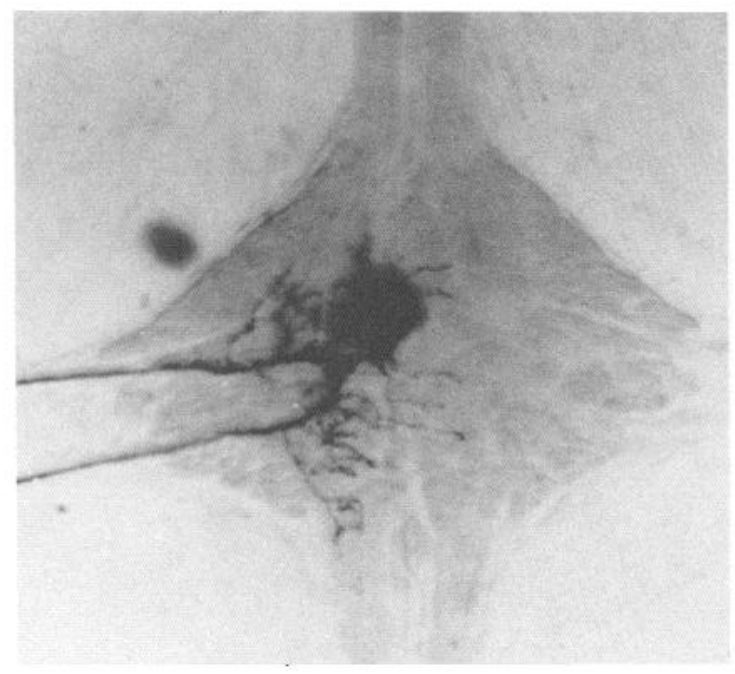

$\mathrm{B}_{1}$

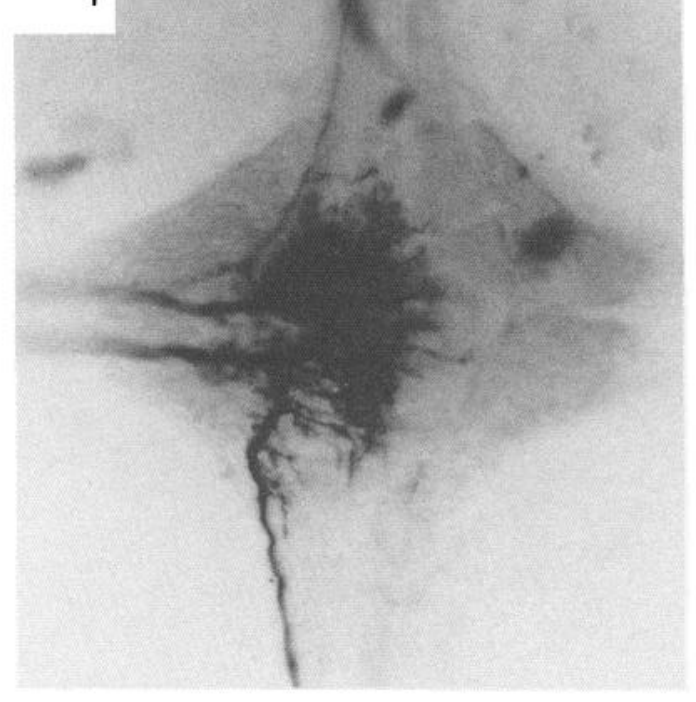

$\mathrm{B}_{2}$

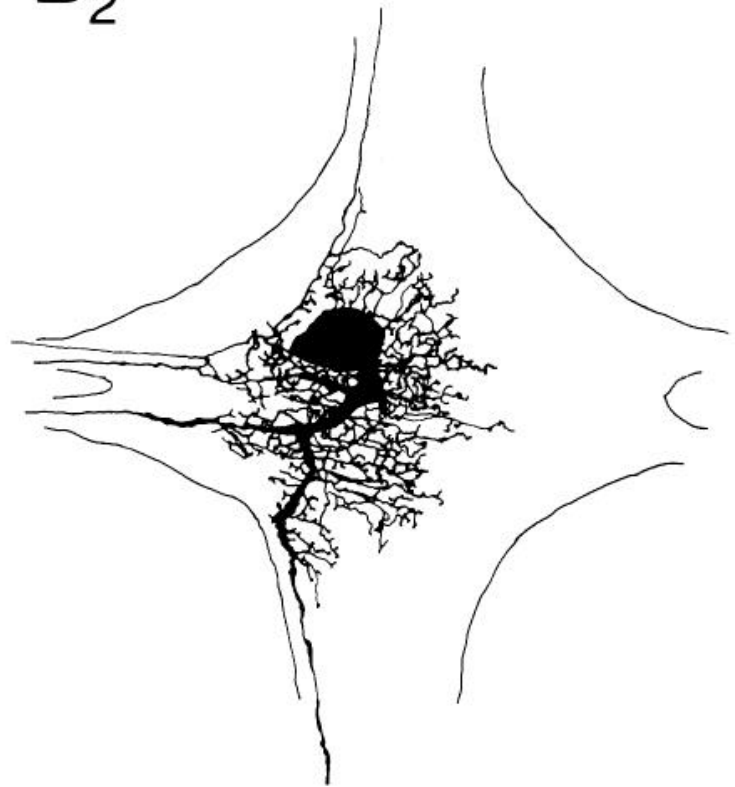

Figure 7. Segmental differences in neuropilar density. Photographs of $(A) \mathrm{Rz}(5)(I)$ and $(B) \mathrm{Rz}(4)(I)$ in the same late stage embryo (day 20$)$, marked intracellularly with HRP. Camera lucida drawings of these cells $(2$, bottom $)$ show all processes regardless of focal plane. Anterior is up, ventral view. Calibration bar, $100 \mu \mathrm{m}$.

cesses fell behind that of their segmental homologs (Fig. 8C). This trend was apparent by about day 14 , and by $20-24 \mathrm{~d}$ the differences in neuropilar density were statistically significant.

\section{Discussion}

As demonstrated in this and previous (Glover, 1984; Glover and Mason, 1986) studies, $\mathrm{Rz}(5,6)$ differ from all other seg- mental $\mathrm{Rz}$ cells in 2 general respects. First, $\mathrm{Rz}(5,6)$ select different targets in the periphery, innervating reproductive tissue rather than body wall and skin. Second, there are subsequent changes in the CNS morphologies of $\mathrm{Rz}(5,6)$ that set them apart from their segmental homologs: they lack intersegmental axons, their somata are smaller, and they have less extensive neuropilar processes. 


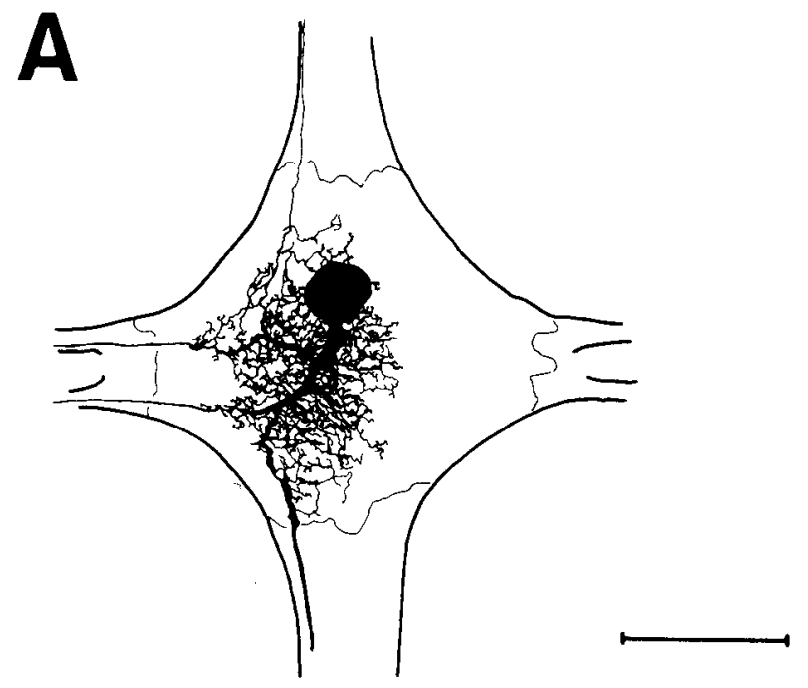

B

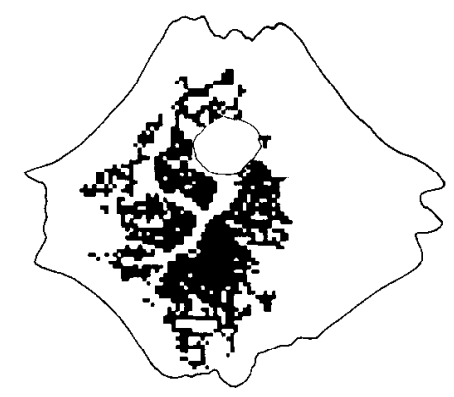

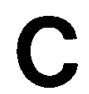

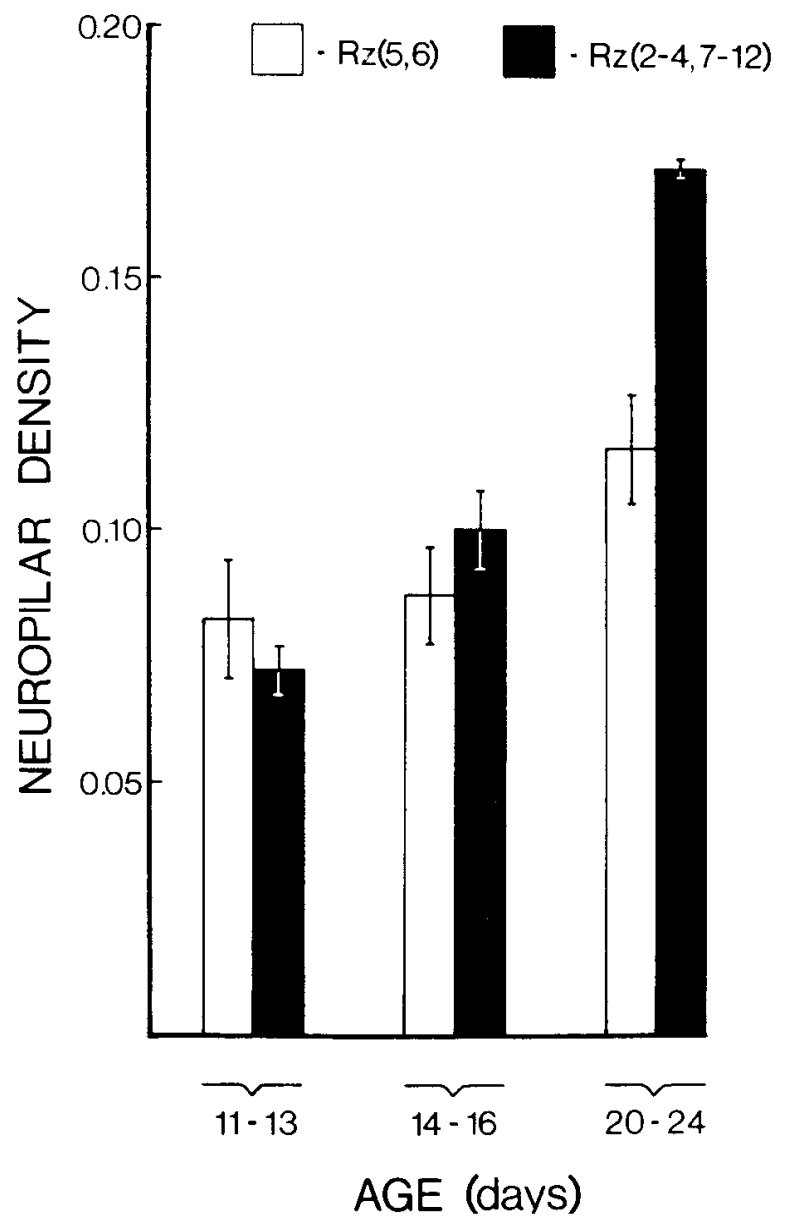

Figure 8. Developmental of segmental differences in neuropilar density. $A$, Camera lucida reconstruction of $\mathrm{Rz}(4)$. $B$, The quantified neuropilar field of this same neuron (see Materials and Methods). The ganglionic outline was drawn as delineated by neuronal somata at the connectives and roots. Anterior is up, ventral view. $C$, Histograms were compiled from data such as those in $A$ and $B$. The open bars are pooled data from $\mathrm{Rz}(5,6)$, while the black bars are pooled data from all other $\mathrm{Rz}$ cells examined. Statistically significant differences $(p<$ 0.01 ; Student's $t$ test) were not apparent until quite late in embryogenesis, at least after 16 d. Error bars denote \pm SEM.

$\mathrm{Rz}(5,6)$ may carry different intrinsic information that directs the development of their unique character. While most segments in the leech are similar, there are certainly some differences that would be difficult to explain without segment- specific activation of the genome. Segments 5 and 6 , which have male and female reproductive structures (Fig. 2), also have extra neurons in their segmental ganglia (Macagno, 1980), 2 pairs of which have been identified as motoneurons causing penile ever- 
sion (Zipser, 1979). Cell counts in these ganglia indicate that the additional neurons start to appear only very late in embryonic life, between days 20 and 30 (Stewart and Macagno, 1984). In addition, the first 4 and last 7 segmental ganglia are fused (Payton, 1981) and have neuronal similarities as well as differences compared to midbody segments (Yau, 1976). There are also structures, such as the testes and ncphridia, that are present only in some, but not all, segments.

Alternatively, $\mathrm{Rz}(5,6)$ may be intrinsically indistinguishable from their segmental homologs. The segmental differences between $\mathrm{Rz}$ cells might then result from interactions with the different targets available to them in particular segments.

\section{Target selection}

The processes of $\mathrm{Rz}(5,6)$ grow out of the ganglia and into the body wall as far as those of the other $\mathrm{Rz}$ cells for more than a day, and their posterior processes are within reach of both the body wall and the reproductive primordia during this time (Fig. 4). These processes may actively select reproductive tissue over body wall. One mechanism by which this might occur, selective adhesion of filopodia, has been proposed as an explanation of directed growth of processes in tissue culture (Bray, 1982; Letourneau, 1982; Bonhoeffer and Huf, 1985), and has been implicated in the mechanism of directed growth for both invertebrate (Goodman et al., 1982; Bentley and Caudy, 1983; Caudy and Bentley, 1986a, b) and vertebrate (Tosney and Landmesser, 1985) neuronal processes in vivo. We know that there is no general incompatibility between $\mathrm{Rz}$ cells and either target, since it has been shown that standard $\mathrm{Rz}$ cells can innervate transplanted reproductive tissue (Loer et al., 1985) and that $\mathrm{Rz}(5,6)$ innervate body wall when denied access to reproductive tissue (Loer et al., 1986, 1987).

By contrast, the anterior processes of $\mathrm{Rz}(5,6)$ are distant from the male reproductive tissue, which suggests that the male tissue might induce directed growth. The distance involved (up to 150 $\mu \mathrm{m}$ ) necessitates a different mechanism than direct contact and selective adhesion to the reproductive tissue. Perhaps the male tissue exudes a substance that maintains processes growing in its direction, a mechanism proposed for the function of nerve growth factor (Campenot, 1982). It is also possible that the processes choose between defined pathways provided by the extracellular matrix (McMahan et al., 1980), pioneer neurons (Bate, 1976; Raper et al., 1983), or other discrete cellular substrates (Kuwada, 1985). Recent work (Jellies and Kristan, 1986) strongly supports the third alternative for the development of the $\mathrm{Rz}(6)$ axon toward the male tissue.

\section{Subsequent morphological changes}

Whether $\mathrm{Rz}(5,6)$ "choose" reproductive tissue as a target or are "prespecified" to it, the question remains: Do target interactions play a role in causing $\operatorname{Rz}(5,6)$ to assume unique segmental characteristics? It has been shown here that there is a temporal correlation between innervation of the segmentally unique target (reproductive tissue) and the morphological changes that follow. Whether this correlation indicates a causal relationship between target selection and the phenotypic specification of $\mathrm{Rz}(5,6)$ can be tested by removing the reproductive tissue early in development and subsequently examining $R z(5,6)$. In the following paper (Loer et al., 1987), results are presented that demonstrate that the morphological differences between $\mathrm{Rz}(5,6)$ and standard $\mathrm{Rz}$ cells can be at least partially eliminated by ablating the reproductive tissue.

\section{References}

Anderson, H. (1985) The development of projections and connections from transplanted locust sensory neurons. J. Embryol. Exp. Morphol. 85: 207-224.

Bate, C. M. (1976) Pioneer neurones in an insect embryo. Nature 260: 54-56.

Bate, C. M., C. S. Goodman, and N. C. Spitzer (1981) Embryonic development of identified neurons: Segment-specific differences in the $\mathrm{H}$ cell homologues. J. Neurosci. 1: 103-106.

Bentley, D., and M. Caudy (1983) Navigational substrates for peripheral pioneer growth cones: Limb-axis polarity, limb-segment boundaries and guidepost neurons. Cold Spring Harbor Symp. Quant. Biol. 48: 573-585.

Bonhoeffer, F., and J. Huf (1985) Position-dependent properties of retinal axons and their growth cones. Nature 315: 409-410.

Bray, D. (1982) Filopodial contraction and growth cone guidance. In Cell Behaviour, R. Bellairs, A. Curtis and G. Dunn, eds., pp. 299317, Cambridge U. P., Cambridge, UK.

Campenot, R. B. (1982) Development of sympathetic neurons in compartmentalized cultures. II. Local control of neurite survival by nerve growth factor. Dev. Biol. 93: 13-21.

Caudy, M., and D. Bentley (1986a) Pioneer growth cone morphologies reveal proximal increases in substrate affinity within leg segments of grasshopper embryos. J. Neurosci. 6: 364-379.

Caudy, M., and D. Bentley (1986b) Pioneer growth cone steering along a series of neuronal and non-neuronal cues of different affinities. $J$. Neurosci. 6: 1781-1795.

Chalfie, M., J. N. Thompson, and J. E. Sulston (1983) Induction of neuronal branching in Caenorhabditis elegans. Science 221:61-63.

Fernandez, J., and G. S. Stent (1982) Embryonic development of the hirudinid leech Hirudo medicinalis: structure, development and segmentation of the germinal plate. J. Embryol. Exp. Morphol. 72: 7196.

Ghysen, A., J. Renaud, and D. Santamaria (1983) Segmental determination of sensory neurons in Drosophila. Dev. Biol. 99: 7-26.

Gillon, J. W., and B. G. Wallace (1984) Segmental variation in the arborization of identified neurons in the leech central nervous system. J. Comp. Neurol. 228: 142-148.

Glover, J. C. (1984) Structure, function, and development of serotonin-containing neurons in the leech. Doctoral thesis, University of California, Berkeley.

Glover, J. C., and A. Mason (1986) Morphogenesis of an identified leech neuron: Segmental specification of axonal outgrowth. Dev. Biol. 115: $256-260$.

Goodman, C. S., J. A. Raper, R. K. Ho, and S. Chang (1982) Pathfinding by neuronal growth cones in grasshopper embryos. Symp. Soc. Dev. Biol. 40: 275-316.

Jellies, J., and W. B. Kristan, Jr. (1986) Axonal guidance provided by non-neuronal cells in the leech. Soc. Neurosci. Abstr. 12: 1336.

Johansen, J., S. Hockfield, and R. D. G. McKay (1984) Distribution and morphology of nociceptive cells in the CNS of three species of leeches. J. Comp. Neurol. 226: 263-273.

Kristan, W. B., Jr., G. S. Stent, and C. A. Ort (1974) Neuronal control of swimming in the medicinal leech. I. Dynamics of the swimming rhythm. J. Comp. Physiol. 94: 97-119.

Kuwada, J. Y. (1985) Pioneering and pathfinding by an identified neuron in the embryonic leech. J. Fmbryol. Exp. Morphol. 86: 155167.

Kuwada, J. Y., and A. P. Kramer (1983) Embryonic development of the leech nervous system: Primary axon outgrowth of identified neurons. J. Neurosci. 3: 2098-2111.

Larimer, J. L., A. C. Eggleston, L. M. Masukawa, and D. Kennedy (1971) The different connections and motor outputs of lateral and medial giant fibres in the crayfish. J. Exp. Biol. 54: 391-402.

Lent, C. M. (1973) Retzius cells: Neuroeffectors controlling mucus release by leech. Science 179: 693-696.

Letourneau, P. C. (1982) Nerve fiber growth and its regulation by extrinsic factors. In Neuronal Development, N. C. Spitzer, ed., pp. 213-254, Plenum, New York.

Loer, C. M., J. Jellies, and W. B. Kristan, Jr. (1985) The possible role of target interactions in the development of segment-specific differences of an identified neuron. Soc. Neurosci. Abstr. 11: 957.

Loer, C. M., C. Schley, B. Zipser, and W. B. Kristan, Jr. (1986) Development of segmental differences in the pressure mechanosensory 
neurons of the leech Haementeria ghilianii. J. Comp. Neurol. 254: 403-409.

Loer, C. M., J. Jellies, and W. B. Kristan, Jr. (1987) Segment-specific morphogenesis of leech Retzius neurons requires particular peripheral targets. J. Neurosci. 7: 2630-2638.

Macagno, E. R. (1980) Number and distribution of neurons in the leech segmental ganglion. J. Comp. Neurol. 190: 283-302.

Mason, A., and W. B. Kristan, Ir. (1982) Neuronal excitation, inhibition and modulation on leech longitudinal muscle. J. Comp. Physiol. 146 : 527-536.

Mason, A., A. J. Sunderland, and L. D. Leake (1979) Effects of leech Retzius cells on body wall muscles. Comp. Biochem. Physiol. (C) 63 : 359-361.

McMahan, V. J., D. R. Edgington, and D. P. Kuffler (1980) Factors that influence regeneration of the neuromuscular junction. J. Exp. Biol. 89: 31-42.

Mittenthal, J. E., and J. J. Wine (1978) Segmental homology and variation in flexor motoneurons of the crayfish abdomen. J. Comp. Neurol. 177: 311-334.

Muller, K. J., J. G. Nicholls, and G. S. Stent (1981) Neurobiology of the Leech, Cold Spring Harbor Laboratory, Cold Spring Harbor, NY.

Payton, B. (1981) Structure of the leech nervous system. In Neurobiology of the Leech, K. J. Muller, J. G. Nicholls, and G. S. Stent, eds., pp. 35-50, Cold Spring Harbor Laboratory, Cold Spring Harbor, NY.

Raper, J. A., M. Bastiani, and C. S. Goodman (1983) Pathfinding by neuronal growth cones in grasshopper embryos. II. Selective fasciculation onto specific axonal pathways. J. Neurosci. 3: 31-41.

Shafer, M. R., and R. L. Calabrese (1981) Similarities and differences in the structure of segmentally homologous neurons that control the hearts in the leech, Hirudo medicinalis. Cell Tissue Res. 214: 137153.

Stefanini, M., C. DeMartino, and L. Zamboni (1967) Fixation of ejaculated spermatozoa for electron microscopy. Nature 216: 173-174.

Stewart, R. R., and E. R. Macagno (1984) The development of segmental differences in cell number in the CNS of the leech. Soc. Neurosci. Abstr. 10:512.

Stewart, W. W. (1978) Functional connections between cells as revealed by dye-coupling with a highly fluorescent napthalamide tracer. Cell 14: 741-759.

Tosney, K. W., and L. T. Landmesser (1985) Specificity of early motoneuron growth cone outgrowth in the chick embryo. J. Neurosci. 5: 2336-2344.

Weeks, J. C., and J. W. Truman (1985) Independent steroid control of the fates of motoneurons and their muscles during insect metamorphosis. J. Neurosci. 5: 2290-2300.

Willard, A. L. (1981) Effects of serotonin on the generation of the motor program for swimming by the medicinal leech. J. Neurosci. 1 : 936-944.

Wilson, J. A. (1979) The structure and function of serially homologous leg motor neurons in locust. II. Physiology. J. Neurobiol. 10: 153167.

Yau, K.-W. (1976) Physiological properties and receptive fields of mechanosensory neurons in the head ganglion of the leech: Comparison with homologous cells in segmental ganglia. Proc. R. Soc. Lond. [Biol.] 199: 567-585.

Zipser, B. (1979) Identifiable neurons controlling penile eversion in the leech. J. Neurophysiol. 42: 455-464. 